\title{
A Move towards Cashless Economy: A Case of Continuous Usage of Mobile Wallets in India
}

\author{
Susmi Routray, Reema Khurana, Ruchi Payal, Rakesh Gupta \\ IMT, Ghaziabad, India \\ Email: sroutray@imt.edu,rkhurana@imt.edu,rpayal@imt.edu,rgupta@imt.edu
}

How to cite this paper: Routray, S., Khurana, R., Payal, R. and Gupta, R. (2019) A Move towards Cashless Economy: A Case of Continuous Usage of Mobile Wallets in India. Theoretical Economics Letters, 9, 1152-1166.

https://doi.org/10.4236/tel.2019.94074

Received: March 7, 2019

Accepted: April 26, 2019

Published: April 29, 2019

Copyright () 2019 by author(s) and Scientific Research Publishing Inc. This work is licensed under the Creative Commons Attribution International License (CC BY 4.0).

http://creativecommons.org/licenses/by/4.0/

\begin{abstract}
Purpose: India is trying to move from cash-dominant economy to cashless economy using digital technologies namely mobile wallets and digital money. A large number of companies have launched their mobile wallet services and people have also rapidly adopted of mobile wallets. However, there is lot of user switching among mobile wallets of different service providers. In such a scenario, it becomes imperative for the mobile wallet service providers to understand the quality factors that support continuous intention of use of mobile wallets by the customers. Very few researchers have focused on the quality aspects as antecedents of the mobile wallets usage like information quality, system quality and service quality. This research study aims to fill this gap by analyzing a research model integrating the two concepts of technology acceptance and quality. Research Methodology: Data were collected from mobile wallet users in India. Structural Equation modelling was used to analyze the data. Findings: The study found that information quality of the mobile wallets significantly impacts perceived usefulness however a significant impact of system quality and service quality on perceived usefulness was not found. The study found that system quality and service quality of the mobile wallets significantly impacts perceived security. Perceived usefulness and perceived security were found to have significant impact on continuous intention to use among the mobile wallet users. Originality: This study will provide insights to the technology developers, managers and mobile payment service providers to focus on the quality aspects of the technology along with the value proposition. This is one of the few research studies to study the quality aspects of the mobile wallets as a technology.
\end{abstract}

\section{Keywords}

Demonetization, Mobile Wallets, Continuous Intention of Use 


\section{Introduction}

Mobile wallets in India are a fairly new mode of payment, it initially started in the last decade, when the Oxigen wallet was launched in 2004 [1]. Subsequently other more popular wallets like PayTM was launched in 2010, currently it has a subscriber base of almost 20 million users. Also MobiKwik is a mobile wallet with a subscriber base of 40 million users. Indian government has also launched a mobile wallets known as Bhim introduced by National Payments Corporation of India [2] and State Bank Buddy [1] introduced by a nationalized bank State Bank of India. Mobile wallet is a mechanism to carry the debit and credit card information on the mobile phone so that transactions may be made without carrying the physical card. It can be used for transactions like making bill payments, ticketing, paying fees electronically.

Also, recent advancements in mobile technologies, specifically in mobile wallet area, has opened up opportunities for unbanked citizens to access financial services [3]. In a developing country like India, mobile wallets are also doubling up as banks for the population not having bank accounts [4]. Indian government has introduced many schemes which propel users to mobile wallets, like introduction of cashless transactions in railways and in toll plazas on highways. In the demonetization drive November 2016, Indian government banned the Rs 500 and Rs 1000 notes there by increasing the dependence on mobile wallets. During demonetization drive it was reported that there was- " $700 \%$ increase in overall traffic on the platform and $1000 \%$ growth in the value of money added to Paytm accounts. In addition, the average transaction value has increased by $200 \%$ and the number of mobile app downloads by 300\%." [5] [6]. This demonetization drive provided a push towards a less-cash society. Mobile wallets can bring around the turnaround in India which has otherwise been a cash dominant society.

For mobile wallet service providers, it becomes inherently important to retain users so that, they keep using their services. The following study is done with an objective to identify the impact of quality factors of mobile wallets for continuous intention of users to use mobile wallets in Indian economy. In this study the quality factors have been integrated with technology acceptance model to study the continuous intention of users.

The subsequent part of this paper is designed as follows: first, the paper briefly reviews the literature on information quality, system quality, system quality, perceived usefulness, perceived security, continuous intention to use and develops a conceptual framework based on the same. The subsequent section elaborates upon and justifies the research methodology used. The next section analyzes the data and discusses the results. Finally, the paper provides a discussion on the findings and highlights the limitations of the work and point towards future direction of research.

\section{Literature Review}

Many researchers have studied the antecedents of continuous usage of any technol- 
ogy. Many researchers have employed Technology Adoption Model (TAM), an information systems theory to investigate the intention behind accepting new technologies by the people. Extensions of TAM model have been provided by the researchers as the two constructs do not completely explain reasons for the continuous use of technology by people. Liebana-Cabanillasa et al. [6] reported that perceived usefulness and perceived security had a positive significant impact on the mobile wallet use. Cao et al. [7] explored the effect of "trust in mobile payment" on intention of users to continue using the technology. Kumar et al. [8] found that perceived usefulness, perceived ese of use, perceived security, trust, grievance redressal and satisfaction had an important effect on consumer's intention to use mobile wallets. Fan et al. [9] indicated that security measures and payment culture have a significant impact on the user attitude towards the usage of mobile wallets. Singh et al. [4] have shown that perception, satisfaction, preference are determiners for the usage of mobile wallets, this study is more relevant to the following research as it is done for the North Indian consumers. There are studies conducted which have identified that perception and satisfaction is gender based in case of mobile wallet usage [10] [11]. It has been examined empirically by Arcand et al. [12] that dimensions of mobile banking service quality (e.g security/privacy, design/aesthetics, sociality and enjoyment) impacts the relationship quality (e.g. trust, commitment and satisfaction). No research has been found which has focused on the quality aspects as antecedents of the mobile wallets usage like information quality, system quality and service quality. This research study aims to fill this gap by analyzing a research model integrating the two concepts of technology acceptance and quality.

\subsection{Quality Characteristics of Mobile Wallets Impacting an Individual User's Continuous Intention to Use Mobile Wallet}

Keyser et al. [13] studied the impact of technical and functional service quality on consumer happiness in a multichannel environment, this study went beyond the SERVQUAL instrument [14] [15] which focused only on service delivery process to include the service-encounter outcomes specifically in case of automated services. However, Keyser et al. [14] was researching in the field of automated services. This research is aimed a specifically studying the intention of the Indian user to continue to use mobile wallet. Thus apparent quality is definitely a reason for sustenance; however, quality may be further broken into different components. Shah et al. [16] depicted that in online environment, the features of a website design significantly affects the website data protection, integrity and confidentiality. Upadhyay \& Jahanyan [17] found that system quality affects perceived usefulness of a mobile based payment transfer. Zhou [18] reported that "structural assurance and information quality are the main factors affecting initial trust, whereas information quality and system quality significantly affect perceived usefulness". Thus System Quality and Information Quality emerged as components of quality impacting Perceived Usefulness, also as mobile wallets is a service, Service Quality [13]) is also taken as a component. Perceived Useful- 
ness has been reported as impacting the user's continued intention to use the mobile wallet [19] [20] [21].

$\mathrm{H}_{1}$ : There is a significant positive relationship between Information Quality and Perceived usefulness.

$\mathrm{H}_{2}$ : There is a significant positive relationship between System Quality and Perceived usefulness.

$\mathrm{H}_{3}$ : There is a significant positive relationship between Service Quality and Perceived usefulness.

$\mathrm{H}_{4}$ : There is a significant positive relationship between Information Quality and Continuous Intention to use.

$\mathrm{H}_{5}$ : There is a significant positive relationship between System Quality and Continuous Intention to use.

$\mathrm{H}_{6}$ : There is a significant positive relationship between Service Quality and Continuous Intention to use.

\subsection{Perceived Usefulness Impacting the User's Continued Intention to Use the Mobile Wallet}

Davis [22] defined perceived usefulness as "the degree to which a person believes that using a particular system would enhance his/her job performance". Upadhyay \& Jahanyan [16] reported that perceived usefulness had a significant impact on continuous intention of using mobile money transfer. Gefen et al. [23] reported that perceived usefulness of an e-commerce web-site had a significant effect on its continuous use intent. Chan \& Chong [24] reported that perceived usefulness had a significant relationship with $\mathrm{m}$-commerce adoption. Zhou [18] reported that performance expectation by the user significantly impacted the continuous use of a mobile payment technology. Bhattacharjee [25] [26] found that perceived usefulness was one of the important antecedents of user's continuous intention to use e-commerce services. Liébana-Cabanillas et al. [6] reported that one of the important factors for continuous intention to use mobile payment systems was its usefulness.

$\mathrm{H}_{7}$ : There is a significant positive relationship between Perceived usefulness and Continuous Intention to use.

\subsection{Perceived Security Impacting the User's Continued Intention to Use the Mobile Wallet}

Hartono et al. [27] reported that perceived security had a significant impact on perceived ease of use, perceived usefulness and continuous intention to use of a technology. Ha et al. [28] researched that Perceived Security has an impact on users' intention to use the website. Salisbury et al. [29] published that Perceived Security is an important determinant for users' choice of using the website. Kumar et al. [8] have reported that Perceived Security is a significant determinant in case of users' continued intention to use mobile wallets. Flavián and Guinalíu, [30] have written that "trust in the internet is particularly influenced by the security perceived by consumers regarding the handling of their private data". 
Chellappa and Pavlou [31] have found that "consumer trust in electronic commerce transactions is influenced by perceived information security". Taherdoost [32] researched that "considering the high significance of perceived security, it is concluded that enhanced feelings of security will result in improved perception of quality. Furthermore, it is found that users will intend to use e-service if they feel that the quality of e-service is high.”. Vinhal Nepomuceno et al. [33] identified security as the most relevant concern in e-commerce. In the above literature surveys it has been observed that most of the research papers cited have studied the impact of perceived security on users' intention to use one or the other digital media. Very few studies were found where the impact of perceived security only in mobile wallet transactions were studied.

$\mathrm{H}_{8}$ : There is a significant positive relationship between Perceived security and Continuous Intention to use.

$\mathrm{H}_{9}$ : There is a significant positive relationship between Perceived Security and Perceived usefulness.

$\mathrm{H}_{10}$ : There is a significant positive relationship between System Quality and Perceived security.

$\mathrm{H}_{11}$ : There is a significant positive relationship between Service Quality and Perceived security.

\subsection{Conceptual Framework}

On the basis of the above literature survey conceptual framework as shown in Figure 1 was conceptualized.

\section{Research Methodology}

\subsection{Instrument Development}

The instrument or the questionnaire for the study was developed by adapting scales from previous researchers to the Indian context. The scales used in the study are mentioned in Table 1.

\subsection{Sample Design}

For this study, people who have been using mobile wallets for at least one year were taken as the target population for the study. For convenience, data was collected from people residing in Delhi NCR only. Delhi/NCR has a high percentage of young population who are tech-savvy and prefer wallets and net banking

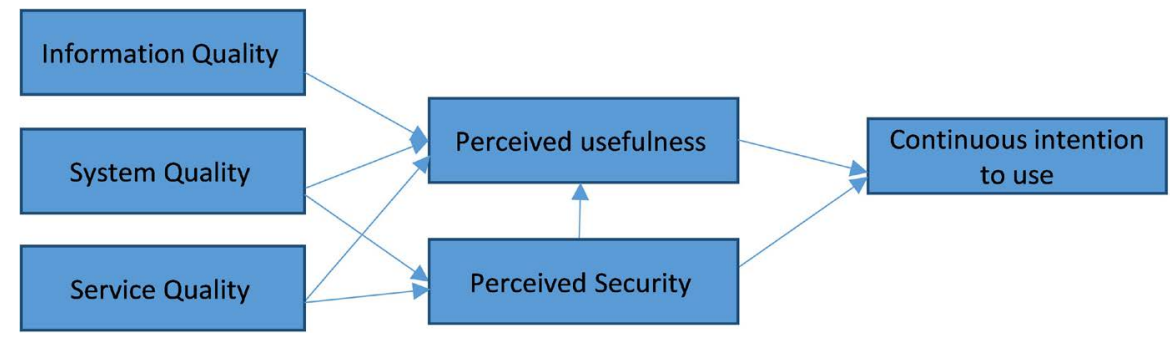

Figure 1. The Conceptual framework. 
Table 1. Scales used in the study.

\begin{tabular}{|c|c|c|c|}
\hline Construct & No. of items & & Source \\
\hline Information Quality & 5 & $\begin{array}{l}\text { Information provided by } \mathrm{m} \text {-wallets is useful } \\
\text { Information provided by } \mathrm{m} \text {-wallets is understandable } \\
\text { Information provided by } \mathrm{m} \text {-wallets is interesting } \\
\text { Information provided by } \mathrm{m} \text {-wallets is reliable } \\
\text { Information provided by } \mathrm{m} \text {-wallets is complete }\end{array}$ & [34] \\
\hline System Quality & 5 & $\begin{array}{l}\text { M-wallet is easy to navigate } \\
\text { M-Wallet alows me to easily find the information I am looking for } \\
\text { M-Wallets are well-structured } \\
\text { M-wallets are easy to use } \\
\text { M-Wallets offer appropriate functionality }\end{array}$ & [34] \\
\hline Service Quality & 4 & $\begin{array}{l}\text { The responsible service personnel provide personal attention when I experience problems with } \\
\mathrm{m} \text {-wallet } \\
\text { The responsible service personnel are always highly willing to help whenever I need support } \\
\text { with the m-wallet } \\
\text { The responsible service personnel provide services related to m-wallets at the promised time. } \\
\text { The responsible service personnel have sufficient knowledge to answer my questions regarding } \\
\text { the m-wallets. }\end{array}$ & [34] \\
\hline Perceived Usefulness & 5 & $\begin{array}{l}\text { Using } \mathrm{m} \text {-wallets simplifies my bill paying life. } \\
\text { I would find it useful to use } \mathrm{m} \text {-wallets to pay for my purchases. } \\
\text { Being able to pay using } \mathrm{m} \text {-wallets, relives me of the burden to carry cash and card. } \\
\text { Using } \mathrm{m} \text {-wallets enhances my effectiveness in managing payments. } \\
\text { M-wallet saves time in making payments. }\end{array}$ & [25] [26] \\
\hline Perceived Security & 4 & $\begin{array}{l}\text { I think my account information is safe in } \mathrm{m} \text {-wallets } \\
\text { I think my account money is safe in } \mathrm{m} \text {-wallets } \\
\text { I think my money transfer is secure and safe in m-wallets. } \\
\text { I think the } \mathrm{m} \text {-wallet is secure of virus. }\end{array}$ & [35] \\
\hline $\begin{array}{l}\text { Continuous intention } \\
\text { to use }\end{array}$ & 3 & $\begin{array}{l}\text { I intend to continue using M-wallet rather than discontinue its use } \\
\text { My intentions are to continue using m-wallet than using any alternative means } \\
\text { If I could, I would like to discontinue my use of m-wallet. }\end{array}$ & [25] [26] \\
\hline Total & 26 & & \\
\hline
\end{tabular}

more than the cash transaction as compared to other cities of India [36] [37]. During the survey, 500 questionnaires were administered to respondents. 250 questionnaires were received back. As per the literature, response rate of $20 \%$ is considered desirable [38] while the response rate for the research study was 50\%. Questionnaire in which a large number of items were not responded to were discarded. After this exercise, 200 responses were observed to be usable. Respondent characteristics are given in Table 2.

\section{Analysis of Data}

\subsection{Assessment of Normality}

Tests for normality were used to choose an appropriate estimation method in Structural Equation modeling [39]. The mean, minimum, maximum, skewness and kurtosis values were noted. Skewness impacts test of means while kurtosis severely affects the test of variances and covariance [40]. Table 3 gives the descriptive statistics of the 26 measurement items. All the skewness values was 
Table 2. Demographic characteristics of respondents.

\begin{tabular}{ccc}
\hline Category & Value & Valid\% \\
\hline \multirow{2}{*}{ Age } & $21-30$ & 90.5 \\
& $31-40$ & 8.2 \\
& $41-50$ & $1.3 \%$ \\
\multirow{2}{*}{ Education } & Graduate & 87.3 \\
& Postgraduate & 12 \\
\multirow{2}{*}{ Gender } & Doctorate & 0.6 \\
& Female & 29.7 \\
& Male & 70.3 \\
\hline
\end{tabular}

Table 3. Descriptive statistics of measurement items.

\begin{tabular}{|c|c|c|c|}
\hline S. No. & Items & Skew & Kurtosis \\
\hline 1 & CI1 & -0.43 & 0.82 \\
\hline 2 & $\mathrm{CI} 2$ & -0.525 & 0.958 \\
\hline 3 & $\mathrm{CI} 3$ & -0.365 & 0.539 \\
\hline 4 & I1 & -0.212 & -0.304 \\
\hline 5 & $\mathrm{I} 2$ & -0.38 & -0.637 \\
\hline 6 & I3 & -0.514 & 0.369 \\
\hline 7 & I4 & -0.537 & 0.375 \\
\hline 8 & I5 & -0.726 & 0.341 \\
\hline 9 & PS1 & -0.408 & -0.706 \\
\hline 10 & PS2 & -0.656 & 0.079 \\
\hline 11 & PS3 & -0.675 & 0.051 \\
\hline 12 & PS4 & -0.166 & -0.252 \\
\hline 13 & PU1 & -1.165 & 1.711 \\
\hline 14 & PU2 & -0.998 & 1.594 \\
\hline 15 & PU3 & -1.119 & 0.988 \\
\hline 16 & PU4 & -0.921 & 0.745 \\
\hline 17 & PU5 & -1.159 & 1.717 \\
\hline 18 & S1 & -1.091 & 2.053 \\
\hline 19 & S2 & -0.745 & 0.548 \\
\hline 20 & S3 & -0.731 & 0.582 \\
\hline 21 & S4 & -1.099 & 1.287 \\
\hline 22 & S5 & -0.885 & 1.753 \\
\hline 23 & SE1 & -0.319 & -0.473 \\
\hline 24 & SE2 & -0.294 & -0.043 \\
\hline 25 & SE3 & -0.453 & -0.022 \\
\hline \multirow[t]{2}{*}{26} & SE4 & -0.052 & -0.247 \\
\hline & Multivariate & & 90.692 \\
\hline
\end{tabular}


lower than the cut-off value of \pm 3.0 [41]. All kurtosis values were also within the cut-off value of \pm 7.0 [41]. According to Bollen [42], "if Mardia's coefficient is lower than $\mathrm{p}^{\star}(\mathrm{p}+2)$ where $\mathrm{p}=$ number of observed variables, then the combined distribution of the variables is multivariate normal". For the study sample, Mardia's coefficient 243.647 is lower than $p^{*}(p+2)$ where $p=26$ variables. This indicated that the sample data meets the criteria for univariate and multivariate normality. Hence Maximum Likelihood (ML) method shall be used for estimation.

\subsection{Assessment of Measurement Model}

Confirmatory Factor analysis (CFA) was used to assess the reliability and validity of the measurement model. The measurement model consisted of the three first-order constructs of information quality, system quality, service quality, perceived security, perceived usefulness and continuous intention to use mobile wallets. Information quality, system quality, service quality, perceived usefulness and perceived security were independent variables. The first-order construct of "continuous intention to use" was a dependent variable. The software used for the analysis was AMOS 21. CFA assess the measurement model validity by using two approaches: 1) Model-fit indices and 2) construct validity and reliability [40] [43].

\subsubsection{Model Fit}

Before analyzing the path estimates for significance, the fit of the model to the data was assessed. Table 4 presents the model fit results. The Chi-square value was 760.55 with 284 degrees of freedom and a significant p-value. The study had a large sample size of $\mathrm{N}=200$, hence a significant $\mathrm{p}$-value was likely [43]. The alternative fit indices were examined for fitness. The value for normed $\chi^{2}$ was 2.678, the value for CFI was 0.855 with an SRMR of 0.078 . These results were within acceptable limits. Hence the structural model fit was adequate, and path estimates could be examined for significance.

\subsubsection{Convergent and Discriminant Validity}

In the study, convergent validity was measured using factor loadings, $t$-values of the factor loadings, composite reliability (CR) and average variance extracted (AVE). Table 5 presents the convergent validity results. All item loading values within each construct were higher than 0.50 (Hair et al., 2010). All the t-values exceeded 1.96 at $\mathrm{p} \leq$ 0.001(Anderson and Gerbing, 1988). All CR values were

Table 4. Model Fit.

\begin{tabular}{cccc}
\hline FIT Index & Value & Actual Value & Model Fit \\
\hline Chi-Square/df & $<$ 3-Good, $<$-Acceptable, $>5$-Not Acceptable & 2.678 & Good \\
CFI & $>0.90$-Good, $>0$-80-Acceptable, $<0$-80-Not acceptable & 0.855 & Acceptable \\
SRMR & $<0.05$-Good, $<0$-08-Acceptable, $<0.10$ & & Acceptable \\
& -Mediocre,$>0.10$-Poor & 0.078 & A
\end{tabular}

Source: [40] [43] [44]. 
Table 5. Convergent validity.

\begin{tabular}{|c|c|c|c|c|}
\hline Construct & Factor Loading & $\mathrm{t}$ & CR & AVE \\
\hline Service Quality & & & 0.838 & 0.570 \\
\hline SE1 & 0.875 & - & & \\
\hline SE2 & 0.801 & 12.523 & & \\
\hline SE3 & 0.554 & 8.098 & & \\
\hline SE4 & 0.748 & 11.64 & & \\
\hline Perceived Security & & & 0.906 & 0.707 \\
\hline PS1 & 0.803 & - & & \\
\hline PS2 & 0.926 & 15.35 & & \\
\hline PS3 & 0.809 & 13.075 & & \\
\hline PS4 & 0.773 & 12.326 & & \\
\hline Perceived Usefulness & & & 0.865 & 0.564 \\
\hline PU1 & 0.731 & - & & \\
\hline PU2 & 0.731 & 13.394 & & \\
\hline PU3 & 0.731 & 9.692 & & \\
\hline PU4 & 0.731 & 10.193 & & \\
\hline PU5 & 0.731 & 11.147 & & \\
\hline Continuous Intention to Use & & & 0.724 & 0.471 \\
\hline $\mathrm{CI} 1$ & 0.766 & 6.614 & & \\
\hline $\mathrm{CI} 2$ & 0.688 & 6.504 & & \\
\hline $\mathrm{CI} 3$ & 0.567 & - & & \\
\hline Information Quality & & & 0.884 & 0.605 \\
\hline I1 & 0.749 & 12.18 & & \\
\hline $\mathrm{I} 2$ & 0.795 & 13.239 & & \\
\hline I3 & 0.756 & 12.334 & & \\
\hline I4 & 0.853 & - & & \\
\hline I5 & 0.765 & 12.547 & & \\
\hline System Quality & & & 0.898 & 0.639 \\
\hline S1 & 0.834 & 13.937 & & \\
\hline S2 & 0.69 & 10.791 & & \\
\hline S3 & 0.798 & 13.111 & & \\
\hline S4 & 0.827 & - & & \\
\hline S5 & 0.833 & 13.921 & & \\
\hline
\end{tabular}

higher than 0.7 and all CR values were higher than AVE values (Hair et al., 2010). All AVE values were higher than 0.5 except that of the construct of "continuous intention to use". According to Malhotra and Dash [45], "AVE is a more conservative measure than $\mathrm{CR}$. On the basis of $\mathrm{CR}$ alone, the researcher may 
conclude that the convergent validity of the construct is adequate, even though more than $50 \%$ of the variance is due to error.". Thus convergent validity was sufficiently established. The discriminant validity was measured using the square root of the AVE estimate which was larger than the correlations of a construct to any other constructs [45]. Table 6 presents the discriminant validity results.

\subsection{Assessment of Structural Model}

After the assessment of the measurement model, the next step was to test the causal relationships. The critical ratio and significance of path coefficients were used to evaluate the proposed hypotheses. When the critical ratio (CR) associated with a regression weight is greater than 1.96 , the path is significant at the 0.05 level or lowers [38] [43].

Hypotheses $\mathrm{H} 1$ analyzed the link between perceived usefulness and continuous intention to use mobile wallets. The results show that the link between perceived usefulness and continuous intention to use mobile wallets was significant (path estimate $\lambda=0.433 ; \mathrm{t}=4.611 ; \mathrm{p}=0.001$ ).

Hypotheses $\mathrm{H} 2$ analyzed the link between perceived security and continuous intention to use mobile wallets. The results show that perceived security had a significant effect on continuous intention to use mobile wallets (path estimate $\lambda$ $=0.317 ; \mathrm{t}=3.72, \mathrm{p}=0.001$ ).

Hypotheses $\mathrm{H} 3$ analyzed the link between information quality and perceived usefulness of mobile wallets. The results show that the link between information quality and perceived usefulness of mobile wallets was significant (path estimate $\lambda=0.244 ; \mathrm{t}=3.232, \mathrm{p}=0.001)$.

Hypotheses $\mathrm{H} 4$ analyzed the link between system quality and perceived usefulness of mobile wallets. The results show that the link between system quality and perceived usefulness of mobile wallets was not significant (path estimate $\lambda=$ $0.143 ; \mathrm{t}=1.574 ; \mathrm{p}=0.115)$.

Hypotheses $\mathrm{H} 5$ analyzed the link between service quality and perceived usefulness of mobile wallets. The results show that the link between service quality and perceived usefulness of mobile wallets was not significant (path estimate $\lambda=$ $0-0.16 ; \mathrm{t}=-1.952 ; \mathrm{p}=0.051$ ).

Table 6. Discriminant validity.

\begin{tabular}{|c|c|c|c|c|c|c|}
\hline & $\begin{array}{c}\text { Information } \\
\text { Quality }\end{array}$ & $\begin{array}{l}\text { System } \\
\text { Quality }\end{array}$ & $\begin{array}{l}\text { Service } \\
\text { Quality }\end{array}$ & $\begin{array}{l}\text { Perceived } \\
\text { Usefulness }\end{array}$ & $\begin{array}{c}\text { Perceived } \\
\text { Security }\end{array}$ & $\begin{array}{l}\text { Continuous } \\
\text { Intention to Use }\end{array}$ \\
\hline Information Quality & 0.778 & & & & & \\
\hline System Quality & $0.572^{* * *}$ & 0.799 & & & & \\
\hline Service Quality & $0.487^{\star * *}$ & $0.430^{* * *}$ & 0.755 & & & \\
\hline Perceived Usefulness & $0.236^{* *}$ & $0.264^{* *}$ & 0.064 & 0.751 & & \\
\hline Perceived Security & $0.356^{* * *}$ & $0.589^{* * *}$ & $0.467^{\star * *}$ & $0.221^{* *}$ & 0.841 & \\
\hline $\begin{array}{l}\text { Continuous } \\
\text { Intention to Use }\end{array}$ & $0.282^{* *}$ & $0.446^{* * *}$ & $0.213^{*}$ & $0.484^{* * *}$ & $0.407^{\star * *}$ & 0.686 \\
\hline
\end{tabular}


Hypotheses H6 analyzed the link between perceived security and perceived usefulness to use mobile wallets. The results show that the link between perceived security and perceived usefulness to use mobile wallets was not significant (path estimate $\lambda=0.125 ; \mathrm{t}=1.315 ; \mathrm{p}=0.189$ ).

Hypotheses $\mathrm{H} 7$ analyzed the link between system quality and perceived security to use mobile wallets. The results show that the link between system quality and perceived security was significant (path estimate $\lambda=0.509 ; \mathrm{t}=6.929 ; \mathrm{p}=$ 0.001).

Hypotheses $\mathrm{H} 8$ analyzed the link between service quality and perceived security to use mobile wallets. The results show that the link between service quality and perceived security was significant (path estimate $\lambda=0.293 ; \mathrm{t}=4.27 ; \mathrm{p}=$ 0.001) (Table 7).

\section{Discussion, Implication, Limitations and Future Research Directions}

The objective of the study was to identify the factors that impact the continuous intention of users to use mobile wallets by integrating the IS success model and the technology acceptance model. The study reported that (Figure 2) perceived usefulness and perceived security had a significant impact on the continuous intention to use mobile wallets. The study also found that system quality had a positively significant impact on the perceived security of mobile wallets. Also, Service quality had a significant relationship with perceived security of mobile wallets however both system and service quality did not have a significant relationship with perceived usefulness. Information quality had a significant relationship with perceived usefulness.

The study investigates the quality aspects of the continuance intention of mobile wallet users and hence significantly contributes in enhancing the literature related to mobile wallet usage. It provides important insights to the service providers. Service providers must focus on enhancing the information quality, system

Table 7. Hypotheses testing results.

\begin{tabular}{lcccccc}
\hline & Dependent Variable & Independent Variable & $\begin{array}{c}\text { Regression } \\
\text { Estimate }\end{array}$ & SE & t & Sig \\
\hline H1 & Continuous Intention to use & Perceived usefulness & 0.433 & 0.083 & 4.611 & $* * *$ \\
H2 & Continuous Intention to use & Perceived Security & 0.317 & 0.053 & 3.72 & $* * *$ \\
H3 & Perceived usefulness & Information Quality & 0.244 & 0.065 & 3.232 & $* * *$ \\
H4 & Perceived usefulness & System Quality & 0.143 & 0.082 & 1.574 & ns \\
H5 & Perceived usefulness & Service Quality & -0.16 & 0.059 & -1.952 & ns \\
H6 & Perceived usefulness & Perceived Security & 0.125 & 0.067 & 1.135 & ns \\
H7 & Perceived Security & System Quality & 0.509 & 0.094 & 6.929 & $* * *$ \\
H8 & Perceived Security & Service Quality & 0.293 & 0.070 & 4.27 & $* * *$ \\
\hline
\end{tabular}

${ }^{* * *} \mathrm{p}<0.001 ;{ }^{* *} \mathrm{p}<0.05 \mathrm{~ns}=$ Non-Significant. 


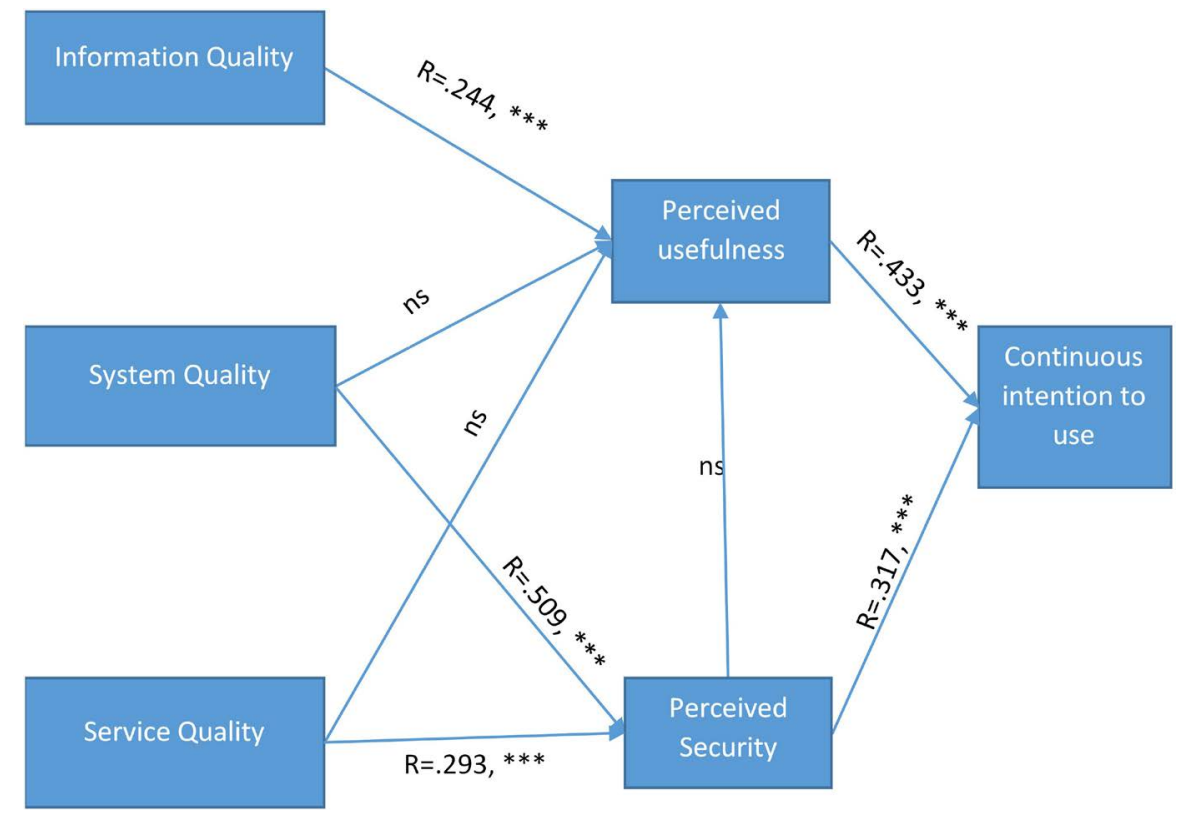

Figure 2. Structural model analysis.

quality and service quality of the mobile wallets. As System quality and service quality impacts the system security which in turn has significant relationship with continuous intention to use the mobile wallets. Also, information quality is an important aspect as it has significant relationship with perceived usefulness. Hence, the mobile service providers need to focus on system, service and information quality to retain their mobile wallet customers.

This study has few limitations. First, this study determines mobile wallet user's perception at a single point of time. Longitudinal study can be conducted to understand change in perception of wallet users. Second, the sample population was limited to young mobile wallet user's residing in north Indian cities of Delhi/NCR and hence may not be representative of perception of total population towards mobile wallets. Future research can include sample from other Indian cities to capture the perception of total Indian population and also compare the perception of the mobile wallet users residing in other Indian cities towards the quality of the mobile wallet.

\section{Conflicts of Interest}

The authors declare no conflicts of interest regarding the publication of this paper.

\section{References}

[1] Jamwal, M. (2017) 10 Digital Wallets in India. http://www.iamwire.com/2017/12/mobile-wallets-best-10-digital-wallets-in-india/1 $\underline{70127}$

[2] Walk through India (2018) Top 5 Mobile Wallets in India for Online Payments. http://www.walkthroughindia.com/hot-trends/top-5-mobile-wallets-india-online-p ayments/ 
[3] Jenkins, B. (2008) Developing Mobile Money Ecosystems. International Finance Corporation and Harvard Kennedy School. Washington DC.

[4] Singh, N., Srivastava, S. and Sinha, N. (2017) Consumer Preference and Satisfaction of M-Wallets: A Study on North Indian Consumers. International Journal of Bank Marketing, 35, 944-965. https://doi.org/10.1108/IJBM-06-2016-0086

[5] Hodiwalla, F. and Aneja, D. (2016) Emergence of E-Wallets in India. Financial Express.

https://www.financialexpress.com/industry/technology/emergence-of-e-wallets-in-i ndia-here-is-how-the-payments-industry-is-growing-rapidly/451008/

[6] Liébana-Cabanillas, F., Marinkovic, V., de Luna, I.R. and Kalinic, Z. (2018) Predicting the Determinants of Mobile Payment Acceptance: A Hybrid SEM-Neural Network Approach. Technological Forecasting and Social Change, 129, 117-130. https://doi.org/10.1016/j.techfore.2017.12.015

[7] Cao, X., Yu, L., Liu, Z., Gong, M. and Adeel, L. (2018) Understanding Mobile Payment Users' Continuance Intention: A Trust Transfer Perspective. Internet Research, 28, 456-476. https://doi.org/10.1108/IntR-11-2016-0359

[8] Kumar, A., Adlakaha, A. and Mukherjee, K. (2018) The Effect of Perceived Security and Grievance Redressal on Continuance Intention to Use M-Wallets in a Developing Country. International Journal of Bank Marketing, 36, 1170-1189. https://doi.org/10.1108/IJBM-04-2017-0077

[9] Fan, J., Shao, M., Li, Y. and Huang, X. (2018) Understanding Users' Attitude toward Mobile Payment Use: A Comparative Study between China and the USA. Industrial Management \& Data Systems, 118, 524-540. https://doi.org/10.1108/IMDS-06-2017-0268

[10] Byoung, H.-J., Pil, K.-H., Jae, W.-C. and Byung, G.-K. (2008) Adoption of on-Line Banking Service Considering the Moderate Effects of on-Line Banking Service Type. 2008 Second International Conference on Future Generation Communication and Networking Symposia, Sanya, 13-15 December 2008, 77-80. https://doi.org/10.1109/FGCNS.2008.98

[11] Dewan, S., Low, G. and Land, L. (2009) Consumer Choice Model of Mobile Banking. Proceedings of the 20 th Australasian Conference on Information Systems, Melbourne, 2-4 December 2009, 25-35.

[12] Arcand, M., PromTep, S., Brun, I. and Rajaobelina, L. (2017) Mobile Banking Service Quality and Customer Relationships. International Journal of Bank Marketing, 35, 1068-1089. https://doi.org/10.1108/IJBM-10-2015-0150

[13] De Keyser, A. and Lariviere, B. (2014) How Technical and Functional Service Quality Drive Consumer Happiness: Moderating Influences of Channel Usage. Journal of Service Management, 25, 30-48. https://doi.org/10.1108/JOSM-04-2013-0109

[14] Parasuraman, A., Zeithaml, V.A. and Berry, L.L. (1985) A Conceptual Model of Service Quality and Its Implications for Future Research. Journal of marketing, 49, 41-50. https://doi.org/10.1177/002224298504900403

[15] Parasuraman, A., Zeithaml, V.A. and Berry, L.L. (1988) Servqual: A Multiple-Item Scale for Measuring Consumer Perceptions of Service Quality. Journal of Retailing, 64, 12-40.

[16] Shah, M.H., Peikari, H.R. and Yasin, N.M. (2014) The Determinants of Individuals' Perceived E-Security: Evidence from Malaysia. International Journal of Information Management, 34, 48-57. https://doi.org/10.1016/j.ijinfomgt.2013.10.001

[17] Upadhyay, P. and Jahanyan, S. (2016) Analyzing User Perspective on the Factors Affecting Use Intention of Mobile Based Transfer Payment. Internet Research, 26, 
38-56. https://doi.org/10.1108/IntR-05-2014-0143

[18] Zhou, T. (2011) An Empirical Examination of Initial Trust in Mobile Banking. Internet Research, 21, 527-540. https://doi.org/10.1108/10662241111176353

[19] Young, W.-S., Kun, C.-L. and Dae, S.-L. (2013) The Impact of Ubiquitous Decision Support Systems on Decision Quality through Individual Absorptive Capacity and Perceived Usefulness. Online Information Review, 37, 101-113. https://doi.org/10.1108/14684521311311658

[20] Jahmani, K., Fadiya, S.O., Abubakar, A.M. and Elrehail, H. (2018) Knowledge Content Quality, Perceived Usefulness, KMS Use for Sharing and Retrieval: A Flock Leadership Application. VINE Journal of Information and Knowledge Management Systems, 48, 470-490. https://doi.org/10.1108/VJIKMS-08-2017-0054

[21] Amin, M., Rezaei, S. and Abolghasemi, M. (2014) User Satisfaction with Mobile Websites: The Impact of Perceived Usefulness (PU), Perceived Ease of Use (PEOU) and Trust. Nankai Business Review International, 5, 258-274.

https://doi.org/10.1108/NBRI-01-2014-0005

[22] Davis, F.D. (1989) Perceived Usefulness, Perceived Ease of Use, and User Acceptance of Information Technology. MIS Quarterly, 13, 319-340.

https://doi.org/10.2307/249008

[23] Gefen, D., Karahanna, E. and Straub, D.W. (2003) Trust and TAM in Online Shopping: An Integrated Model. MIS Quarterly, 27, 51-90. https://doi.org/10.2307/30036519

[24] Chan, F.T.S. and Chong, A.Y.L. (2013) Analysis of the Determinants of Consumers'm-Commerce Usage Activities. Online Information Review, 37, 443-461. https://doi.org/10.1108/OIR-01-2012-0012

[25] Bhattacherjee, A. (2001) An Empirical Analysis of the Antecedents of Electronic Commerce Service Continuance. Decision Support Systems, 32 201-214. https://doi.org/10.1016/S0167-9236(01)00111-7

[26] Bhattacherjee, A. (2001) Understanding Information Systems Continuance: An Expectation-Confirmation Model. MIS Quarterly, 25, 351-370. https://doi.org/10.2307/3250921

[27] Hartono, E., Holsapple, C.W., Kim, K.Y., Na, K.S. and Simpson, J.T. (2014) Measuring Perceived Security in B2C Electronic Commerce Website Usage: A Respecification and Validation. Decision Support Systems, 62, 11-21. https://doi.org/10.1016/j.dss.2014.02.006

[28] Ha, H.Y. and Pan, H. (2018) The Evolution of Perceived Security: The Temporal Role of SNS Information Perceptions. Internet Research, 28, 1055-1078. https://doi.org/10.1108/IntR-02-2017-0047

[29] Salisbury, W.D., Pearson, R.A., Pearson, A.W. and Miller, D.W. (2001) Perceived Security and World Wide Web Purchase Intention. Industrial Management \& Data Systems, 101, 165-177. https://doi.org/10.1108/02635570110390071

[30] Flavián, C. and Guinalíu, M. (2006) Consumer Trust, Perceived Security and Privacy Policy: Three Basic Elements of Loyalty to a Web Site. Industrial Management \& Data Systems, 106, 601-620. https://doi.org/10.1108/02635570610666403

[31] Chellappa, R.K. and Pavlou, P.A. (2002) Perceived Information Security, Financial Liability and Consumer Trust in Electronic Commerce Transactions. Logistics Information Management, 15, 358-368. https://doi.org/10.1108/09576050210447046

[32] Taherdoost, H. (2017) Understanding of E-Service Security Dimensions and Its Effect on Quality and Intention to Use. Information \& Computer Security, 25, 
535-559. https://doi.org/10.1108/ICS-09-2016-0074

[33] Vinhal Nepomuceno, M., Laroche, M., Richard, M.O. and Eggert, A. (2012) Relationship between Intangibility and Perceived Risk: Moderating Effect of Privacy, System Security and General Security Concerns. Journal of Consumer Marketing, 29, 176-189. https://doi.org/10.1108/07363761211221701

[34] Urbach, N., Smolnik, S. and Riempp, G. (2010) An Empirical Investigation of Employee Portal Success. The Journal of Strategic Information Systems, 19, 184-206. https://doi.org/10.1016/j.jsis.2010.06.002

[35] Gao, F., Rau, P.L.P. and Zhang, Y. (2018) Perceived Mobile Information Security and Adoption of Mobile Payment Services in China. In: Mobile Commerce: Concepts, Methodologies, Tools, and Applications, IGI Global, Hershey, PA, 1179-1198. https://doi.org/10.4018/978-1-5225-2599-8.ch055

[36] Bhasker, R.N. (2016) F. India. 16 April. http://www.firstpost.com/india/why-we-shouldbe-worried-about-north-indias-dem ographic-time-bomb-2731954.html

[37] Tech2 (2016) News analysis. Tech2, 12 April. http://tech.firstpost.com/news-analysis/indians-spend-more-time-shopping-than-so cial-networking-when-online-survey-308828.html

[38] Yu, J. and Cooper, H. (1983) A Quantitative Review of Research Design Effects on Response Rates to Questionnaires. Journal of Marketing Research, 20, 36-44. https://doi.org/10.1177/002224378302000105

[39] Kline, R.B. (1998) Methodology in the Social Sciences. Principles and Practice of Structural Equation Modeling. Guilford Press, New York.

[40] Byrne, B.M. (2016) Structural Equation Modelling with AMOS: Basic Concepts, Applications, and Programming. 3rd Edition, Routledge, New York.

[41] West, S.G., Finch, J.F. and Curran, P.J. (1995) Structural Equation Models with Nonnormal Variables: Problems and Remedies. In: Hoyle, R.H., Ed., Structural Equation Modeling: Concepts, Issues, and Applications, Sage, Thousand Oaks, CA, 56-75.

[42] Bollen, K.A. (1989) Structural Equations with Latent Variables. Wiley, New York. https://doi.org/10.1002/9781118619179

[43] Hair, J.F., Black, W.C., Babin, B.J. and Anderson, R.E. (2010) Multivariate Data Analysis. 7th Edition, Prentice Hall, Upper Saddle River, NJ.

[44] Hu, L. and Bentler, P. (1999) Cutoff Criteria for Fit Indices in Covariance Structure Analysis: Conventional Criteria versus New Alternatives. Structural Equation Modeling: A Multidisciplinary Journal, 6, 1-55. https://doi.org/10.1080/10705519909540118

[45] Malhotra Naresh, K. and Dash, S. (2015) Marketing Research, An Applied Orientation. 7th Edition, Pearson, India. 